Original Research Paper

\title{
The Importance of Product Innovation in Driving Brand Success: An Empirical Study on Automotive Industry
}

\author{
Jalal Hanaysha \\ Faculty of Business and Management, DRB-HICOM University of Automotive Malaysia, 26607, Pekan, Pahang, Malaysia
}

Article history

Received: 27-01-2015

Revised: 21-03-2016

Accepted: 26-03-2016

Email: jalal.hanayshi@yahoo.com

\section{Introduction}

Branding is one of the main essential elements in the operationalization of any organization. There are several advantages for acquiring a strong brand name. As reported by past literature, strong brands enjoy high equity by successfully managing customers' responses to various activities that are designed to market their products and services (Keller, 1993). Additionally, obtaining a powerful brand can help an organization to obtain differential marketing advantages and enhance its competitiveness (Hoeffler and Keller, 2003; Keller, 2001). For this reason, it has become vital for organizations to strategically address their competitiveness by looking at the relevant branding strategies that could enable them to ensure long-term brand success and build sustainable competitive advantage (Kumar et al., 2003). Therefore, managing brand equity should be directed towards successful adoption of relevant marketing strategies to satisfy market needs.

Evidently, brand management plays a key role in forming favourable attitude towards an organization
(Curtis et al., 2009). The ability of a brand to successfully obtain high brand equity and influence customers' purchase decisions will in fact provide it with better opportunities to strengthen its global competitiveness and gain favourable image (Keller, 2003). In particular, brand equity represents the key strength of an organization due to the greater benefits that would shape brand success and this topic has attracted several academicians since $1990 \mathrm{~s}$ (Boo et al., 2009). The focus on brand equity in recent years has increased with respect to diverse industry and country contexts. Theoretical literature reveals that brand equity can be assessed based on any of the following three perspectives: Customers' perspective, financial perspective and the combined perspectives (Aaker, 1991; 1996). However, this study focuses only on customer based brand equity. This is because customers are the key assets of any brand where its success largely depends on them.

Brand equity literature shows that a number of factors contribute to the development of firm's brand equity. For example, in automotive industry, product innovation is regarded as one of the main criteria for 
judging the quality and value of a brand. Surprisingly, only few scholars examined the empirical link between product innovation and brand equity (Stock, 2011; Milenkov, 2012), particularly in automotive sector. Besides that, the empirical examination of the link between product innovation and brand equity elements such as brand awareness and brand leadership has been neglected in the literature. Consequently, this study is conducted to contribute to the literature by testing the link between product innovation and brand equity in automotive context. The next sections begin with presenting past literature on the topic and then methodology, analysis of results, limitations and future research direction and conclusion follow.

\section{Literature Review}

\section{Brand Equity}

The increasing attention towards brand equity research indicates the importance of this topic whereby several organizations capitalize on the value of strong brand equity for better strategic marketing (Ross, 2006). According to Aaker (1996), brand equity can be determined based on the capability of a firm to influence consumer behaviour with regard to various elements such as: Brand loyalty, awareness toward the brand, perceptions of product and service quality and consumers' brand associations. The earliest definition of brand equity was introduced in $1980 \mathrm{~s}$ by Farquhar (1989) as the supplementary value that a brand provides on its products or services. This definition is similar to that of Lassar et al. (1995) who expressed brand equity as the ability to enhance customers' perceived value and desirability toward a brand through product and service offerings.

Acquiring strong brand equity enables firms to reinforce their competitive advantages and obtain various marketing advantages over competitors, such as the ability to sell products and services at premium prices and maximizing consumers' demands (Keller, 2003). According to Bendixen et al. (2004), the advantages of strong brand equity appear in the ease and success of brand extensions and making the communication campaigns more effective. They also added that improved brand equity enhances trade leverage; increases profit margins; and decreases organizations' threats. Additionally, Keller (2003) highlighted the benefits of building successful brand equity indicating that it helps a firm to generate differential influence on consumers' purchase decisions, build brand knowledge and develop positive consumers' response to brand marketing that would ultimately lead to improved brand performance.

Several scholars confirmed that brand equity represents the key advantage that shapes brand success and competitiveness through the benefits that it generates over time. Brand equity has been established as an important field in brand management and captured strong attention among high number of scholars in various industrial contexts (Boo et al., 2009). Brand equity is highly related to organizational success due to the fact that successful creation of a strong brand enables the manufacturing firm to generate higher profits and spend fewer expenses on marketing activities (Keller, 2003; Myers, 2003). Recently, brand equity development has become the key focus for firms implementing global marketing strategy considering it as a key strategic tool to obtain competitive advantage and favourable brand image (Moradi and Zarei, 2011).

Past literature showed that several dimensions shape or form brand equity. As stated by Aaker (1991), future researches should measure brand equity using a set of at most four dimensions. Therefore, this study is designed to contribute to brand equity measurements and conceptualization by incorporating brand image, brand awareness, brand loyalty and brand leadership as its key elements. As observed in previous literature, these elements were considered to be important indicators of brand equity, but so far have not been grouped together to measure it. Brand awareness refers to consumers' abilities to recognize or recall a particular brand among others which provide similar offerings (Aaker, 1991). On the other hand, brand loyalty was defined by Yoo and Donthu (2001) as consumers' willingness to develop loyalty intention to a particular brand and this can be reflected through repteitive purchases of that brand. Brand image was proposed by Henard and Dacin (2010) as "the overall perception that the firm is generally perceived in a favorable light".

Finally, brand leadership was defined by Keller (2008) as a brands' ability to influence customers' acceptance of its products and services and prove its presence in international markets. It was primarily proposed as a key asset of brand equity by Aaker (1996) who provided significant contributions to the conceptualization and measurement to this concept. However, surprisingly, most of the past studies have somewhat ignored this important dimension and studied the other frequently used dimensions (brand association, brand strength, brand loyalty, brand image, brand awareness and perceived quality) of brand equity. In relation to that, this paper aims to provide an important contribution to brand equity theory by using brand leadership as a main element of brand equity.

\section{Product Innovation}

The concern towards product innovation has captured the attention of many scholars in the past decades. Nemati et al. (2010) expressed product innovation as the capability of a brand to create, develop and implement new offerings of unique and attractive products or 
services in an attempt to improve the efficiency and effectiveness of a brand and build sustainable competitive advantages. They added that product innovation stems from the firm's ability to create new products with added values or developing existing ones to fulfill consumers' needs to keep their values for the long term. The majority of previous studies on innovation have predominantly focused on product innovation due to its significance in driving organizational growth (Saridan et al., 2008). Indeed, global brands that successfully manage to sustain their products in highly competitive markets are more innovative (Holland et al., 2011). Their innovativeness come from the ability to invest in new product introductions to meet customers' needs (Henard and Dacin, 2010).

Furthermore, product innovation reflects an organizational capability to develop brands through initiating unique offering and it can assist business manufacturers in their branding efforts (Kaplan, 2009). Consumers are likely to develop positive perceptions about brands which emphasize on innovation and developing creative product designs (Holland et al., 2011). This was clearly indicated in the literature suggesting that firms introducing products with unique designs would enable them to deliver important information to their customers with regards to the benefits of purchasing from their brands (Karjalainen, 2006; Muller, 2001) such as positive country of origin image (Monö, 1997). This information are considered to be important in increasing brand awareness and building brand image associations (Schmitt and Simonson, 1997). For instance, product design has been regarded as a key feature for attracting consumers and influencing their evaluations toward the manufacturing brand.

Past literature explained the significance of product innovation as a key factor for driving organizational growth and performance (Chimhundu et al., 2010). For example, integrating innovation activities in the process of manufacturing and business operations would provide a prime help for firms to maintain strong presence in targeted markets (Johne, 1999; Keller, 2003). Moreover, brands that strongly focus on introducing innovative products can enjoy higher profits and growth as compared to those that lack to innovation in their products. Such brands also tend to have higher brand awareness and appeal (Kingsland, 2007). However, although product innovation plays an important role in strengthening brand success, there exists little empirical research that addressed its link with brand equity (Milenkov, 2012). By exploring this relationship, a better understanding will be obtained with regards to the possible association between product innovation and brand equity. Thus, investigating the relationship between both variables would provide useful suggestions and implications for business managers to formulate their strategies in their branding efforts.
Past researches showed that product innovation had significant relationship with brand equity (Sriram et al., 2007; Yang, 2008). The ability of a brand to produce innovative product leads to higher brand equity (Sinapuelas and Sisodiya, 2010). The findings were supported by certain scholars who demonstrated that product innovation had positive association with brand equity (Zhang et al., 2010). Greater support was also established by Henard and Dacin (2010) who confirmed that product innovation had a significant positive relationship with two elements of brand equity; brand image and brand loyalty. Their findings are in line with Ko et al. (2009) who found that innovation can positively influence brand loyalty intentions. Besides, certain scholars found that product innovation activity such as design image had significant positive relationship with brand image, in which the image for appealing product design had a direct association with brand equity (Holland et al., 2011). They further stated that consumers tend to judge product quality based on the features of design. Based on the literature presented above, the hypotheses for this study are proposed as follows:

H1: Product innovation has significant relationship with brand awareness.

H2: Product innovation has significant relationship with brand loyalty.

H3: Product innovation has significant relationship with brand image.

H4: Product innovation has significant relationship with brand leadership.

H5: Product innovation has significant relationship with overall brand equity.

\section{Methodology}

This study adopts quantitative research approach whereby a survey was employed to obtain the data from several owners of passenger cars at different shopping malls in northern Malaysia, particularly at three states: Penang, Kedah and Perlis. The sample was drawn using systematic random sampling procedure in which every 10th leaving customer at selected shopping malls was approached at the entrance to participate in answering the survey. Malhotra (1996) stated that this sampling technique is necessary to represent the population. By referring to Malaysian Automotive Association, the recent figures show that the number of registered passenger cars in these states as until 2014 is more than one million. Krejcie and Morgan (1970) suggested that a study which has a population of one million or more should at least cover a sample size of 384 . Therefore, based on their suggestions, a random sample of 384 is utilized for data collection in this study.

This study adapted several scales from past studied to measure the constructs. For instance, product innovation 
was measured through seven items being taken from Stock (2011); Hanaysha and Hilman (2015) and it is defined as the ability of a brand to update new products with new features and provide new alternatives to customers which differentiate it from competitors. To measure brand equity, four dimensions were used. Aaker (1991; 1996) who is regarded as the well-known scholar in the field of brand equity suggested that brand equity can be measured using a set of four dimensions. Consequently, this study used brand awareness, brand leadership, brand loyalty and brand image as the key components for measuring brand equity. However, the selection of these dimensions depends on the context of this study, which in this case is targeted to evaluate customers' perceptions in automotive context. The number and sources of measurement items of each construct are presented in this section.

Brand awareness was measured in terms of four items being adapted from Yasin et al. (2007) and it refers to the degree by which customers can call or recognize a brand given product category. Similarly, four items were adopted from Nigam and Kaushik (2011) to measure brand loyalty and modified to fit the context of this study. Brand loyalty is defined as affiliation and adherence of customers to a particular brand. Furthermore, brand image is defined as the overall impression developed by customers about a brand and it was measured in this study in terms of five items being taken from Nigam and Kaushik (2011). Finally, brand leadership refers to customer's acceptance of brand popularity and innovation and it was measured through five items being taken from the researches of Aaker (1996) and Liaogang et al. (2007). All of the stated scales were selected because they were reported at acceptable values of Cronbach's alpha of more than 0.70. Moreover, a sven-point Likert scale that ranges from $1=$ strongly disagree to $7=$ strongly agree was used on all items.

\section{Analysis of Results}

To obtain the minimum responses and fulfill the requirements of sample size for data collection, a total of 384 survey were personally distributed on passenger car owners in northern Malaysia. Overall, 287 questionnaires were answered and returned by the respondents representing $74.7 \%$ of response rate. The demographic profile of respondents showed that male respondents accounted for $136(47.4 \%)$ of total response, whereas female represented $151 \quad(52.6 \%)$. The descriptive analysis also showed that 36 of the respondents were 25 years old or below and $140(48.8 \%)$ came in the age group of 25 to 35 years. But, those whose ages ranged between 35 and 45 years accounted for $46(16 \%)$ of total responses, while $65(22.6 \%)$ were in the age category of more than 45 years old. In terms of religious background, Muslims accounted for 216 $(75.3 \%), 42(14.6 \%)$ are Buddhists, $14(4.9 \%)$ are Christians, 13 (4.4\%) are Hindu, whereas 2 respondents $(0.7 \%)$ have other religions. Finally, the demographic analysis showed that $124(43.2 \%)$ of the participants hold a certificate of High school/SPM/PMR, while 62 $(21.6 \%)$ had higher qualification of diploma. Those who had the highest qualification of bachelor degree represented $73(25.4 \%)$ of overall responses, $23(8 \%)$ had postgraduate certificate and only $5(1.7 \%)$ had other qualifications.

To analyze the data which was collected from respondents generate the findings, Structural Equation Modeling (SEM) using AMOS 18 was employed. As AMOS deals only with clean data, this study used different methods for data screening such as: Detecting and replacing missing values, outliers' deletion, normality test and Multicollinearity checking between constructs. All of these issues were settled before testing the model. Specifically, 11 cases form the questionnaires had missing values. The replacement of such values was done according to the median of nearby points taking into consideration that the questionnaires have minor omissions. Moreover, 30 outliers were identified using Mahalanopis distance and deleted. Finally, the correlation results didn't show any Multicollinearity issue between variables since the correlation between any two constructs is less than 0.90 (Tabachnick and Fidell, 2001).

The reliability of constructs was also determined by calculating Cronbach's alpha using SPSS 19. The findings showed that all constructs achieved the minimum value of acceptable reliability Cronbach's alpha; product innovation (0.905), brand awareness $(0.874)$, brand loyalty $(0.859)$, brand image $(0.842)$ and brand leadership (0.858). This indicates that the Cronbach's alpha value for each construct exceeded 0.70 and this provides further support for convergent validity assumptions (Hair et al., 2010). Similarly, Composite reliability was calculated to confirm the internal consistency among the items of each construct and it was found that all constructs achieved acceptable fit; product innovation (0.905), brand awareness (0.874), brand loyalty $(0.860)$, brand image $(0.845)$ and brand leadership (0.862), which means that all are above 0.70 (Appendix A). Therefore, reliability analysis is acceptable and satisfactory.

The validity of constructs was also established on the constructs using Microsoft Excel. The purpose of discriminant validity is to confirm that each set of items represent their own construct and are distinct from those of other constructs. This procedure was done based on the calculations of Average Variance Extracted (AVE). According to Byrne (2010), any value of AVE which is 0.50 or more should be treated as an indication of acceptable discriminant validity for each construct in the model. As shown in Appendix A, it can be said that all 
constructs achieved the cut-off value of 0.5 which provides evidence of existing strong discriminant validity.

Confirmatory Factor Analysis (CFA) is another test which was used for the purpose of confirming the factor loadings of each construct (product innovation, brand awareness, brand loyalty, brand image and brand leadership). Overall, the findings yielded acceptable values on the factor loadings of all constructs in the range of 0.66 to 0.95 . Besides, in order to achieve a good model fit, a structural model was estimated using AMOS 18. The final model as shown in Figure 1 indicates that a significant chi-square $(281.079, \mathrm{p}<0.05)$ is achieved, given the adequate sample size employed in this study. To support the assumptions of model fit, other fit values were used $(\mathrm{GFI}=0.909$, AGFI $=0.886$, TLI $=0.965$, CFI $=0.969$ and RMSEA $=0.045)$. Consequently, it can be concluded that the structural model achieved reasonable fit for the data as suggested by (Hair et al., 2010).

Based on the model which is shown above in Fig. 1, the results of hypotheses were generated. Interestingly, the findings supported all of the proposed hypotheses which were presented in the literature review section. Table 1 shows that a significant positive relationship between product innovation and brand awareness is established in this study $(\beta=0.285, \mathrm{CR}=4.298, \mathrm{p}=<$ $0.001)$, thus, $\mathrm{H} 1$ is accepted. The results also indicate that product innovation has significant positive relationship with brand loyalty $(\beta=0.498, \mathrm{CR}=6.848$, $\mathrm{p}=<0.001)$ and this means that $\mathrm{H} 2$ is supported. The significant positive relationship between product innovation and brand image was also supported $(\beta=$ $0.497, \mathrm{CR}=6.622, \mathrm{p}=<0.001)$, therefore $\mathrm{H} 3$ is accepted. Moreover, the results showed that product innovation has significant positive relationship with brand leadership $(\beta=0.431, \mathrm{CR}=5.742, \mathrm{p}=<0.001)$, thus $\mathrm{H} 4$ is also accepted. Finally, the relationship between product innovation and overall brand equity is supported $(\beta=0.528, \mathrm{CR}=2.765, \mathrm{p}=<0.005)$, therefore, H5 is accepted. In general, the findings indicate that product innovation explains $28 \%$ of variance in brand equity.

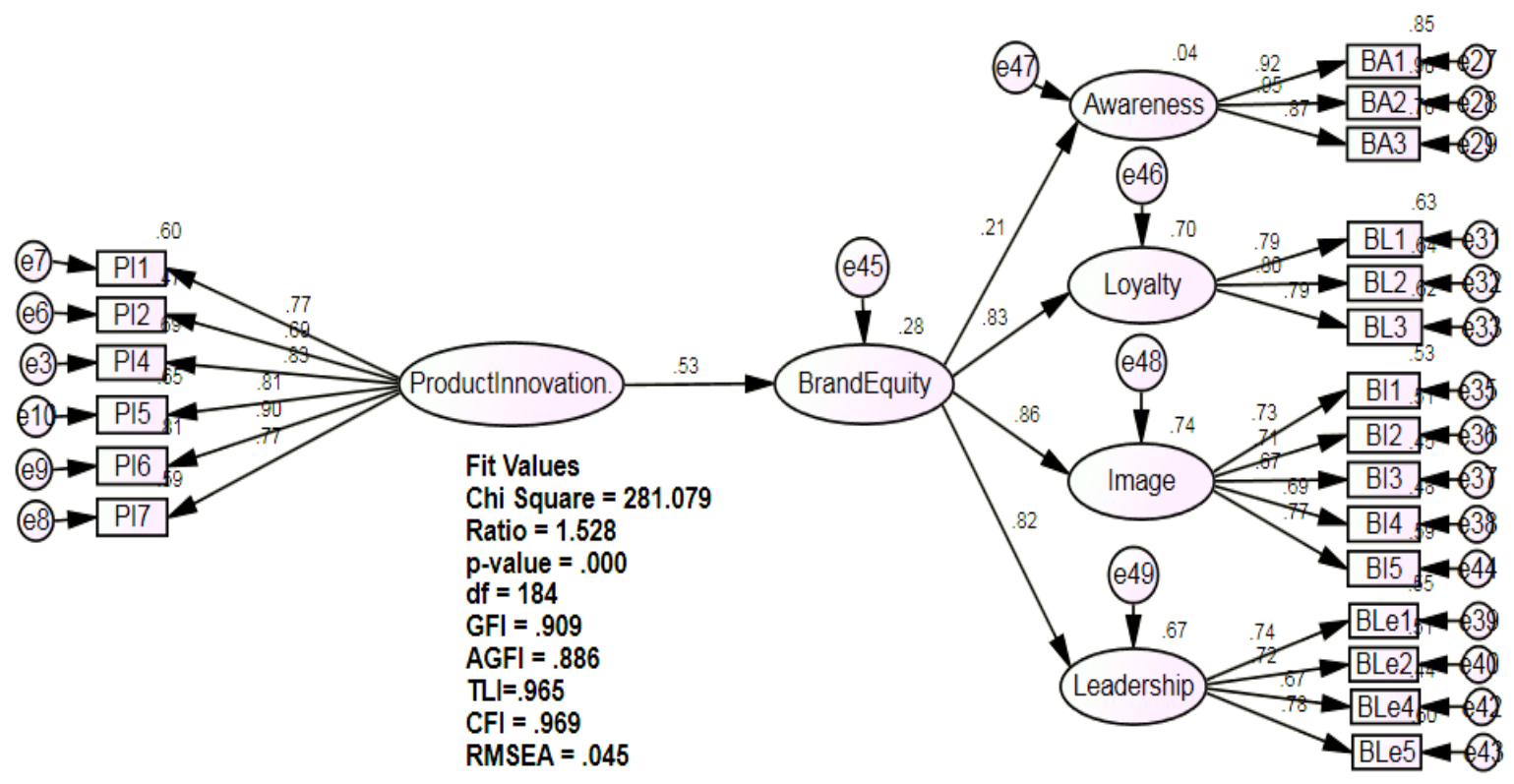

Fig. 1. Structural model

Table 1. Research findings

\begin{tabular}{|c|c|c|c|c|c|c|}
\hline & Hypothesis & Std. Estimate & S.E. & C.R. & $\mathrm{P}$ & Support \\
\hline$\overline{\mathrm{H} 1:}$ & $\begin{array}{l}\text { Product innovation has significant } \\
\text { relationship with brand awareness }\end{array}$ & 0.285 & 0.067 & 4.298 & $* * *$ & Yes \\
\hline $\mathrm{H} 2$ : & $\begin{array}{l}\text { Product innovation has significant } \\
\text { relationship with brand loyalty }\end{array}$ & 0.498 & 0.088 & 6.848 & $* * *$ & Yes \\
\hline H3: & $\begin{array}{l}\text { Product innovation has significant } \\
\text { relationship with brand image }\end{array}$ & 0.497 & 0.083 & 6.622 & $* * *$ & Yes \\
\hline H4: & $\begin{array}{l}\text { Product innovation has significant } \\
\text { relationship with brand leadership }\end{array}$ & 0.431 & 0.089 & 5.742 & $* * *$ & Yes \\
\hline H5: & $\begin{array}{l}\text { Product innovation has significant } \\
\text { relationship with overall brand equity }\end{array}$ & 0.528 & 0.040 & 2.765 & 0.006 & Yes \\
\hline
\end{tabular}




\section{Discussion}

Product innovation is considered to be important for organizations due to globally competitive environments. It has received significant attention from several organizations that successfully managed to build strong brand name in international markets. This is because new products with innovative and attractive features contribute significantly to increased sales revenues. Additionally, when an organization has the capability to develop differentiated products, it will as a result gain advantages to charge premium prices. Previous literature also confirmed that product innovation is necessary to business survival and growth in the presence of competitors (Keller, 2003; Henard and Dacin, 2010). By focusing on product innovation, a brand can gain higher loyalty from its customers and minimizes price sensitivity as a result of customers' appreciation to the uniqueness of innovation which reflects the capability of that brand (Lieberman and Montgomery, 1988).

The main purpose of this study was to test the direct link between product innovation and brand equity in Malaysian automotive market. Overall, the results indicated that product innovation has significant positive relationship with brand equity and its dimensions; brand image, brand awareness, brand loyalty and brand leadership. These results are expected; because powerful and leading brands strongly emphasize on product innovation by integrating it into the main strategies to ensure business excellence. Greater support was reported by Hanaysha and Hilman (2015) who found that product innovation had significant relationship with brand equity and its dimensions. Central to brand equity are issues related to increasing the levels of product innovation which is dependent on the ability of a brand to lead competitively in a particular marketplace (Otubanjo, 2013). Keller (2003) declared that global brands inspire the image of product innovation status among their customers to enhance their positions in target markets. Such emphasis would drive the success and value of their brand on the long term and forms the basis of competitive advantage.

Beverland et al. (2007) added that powerful brands are considered to be influential in attracting customers through focusing on the dimensions of product innovation. This is due to the fact that maintaining good record of product innovations lead to sustainable competitive advantage and long term performance. Therefore, product innovation is one of the important factors for driving brand success and creating strong brand equity. Thus, it is recommended that automotive manufacturers should put greater efforts toward improving their product innovation activities to meet the needs and satisfaction of their customer. By doing so, they can improve their brand equities on the long run and it would be possible for such brands which integrate product innovation into their strategic operation to become among the leading edge in markets.

This study was also designed to contribute to dynamic capabilities perspective by providing empirical evidence on the positive link between product innovation and brand equity. Certain scholars (Chu and Keh, 2006; Rubio and Yague, 2009) revealed that product innovation is a key variable that influences both market share and brand equity. Moreover, Davcik and Grigoriou (2013) reported that by applying different innovation types, such as technology and production standards, firms would have better opportunities to build and sustain brand equity. Hence, by placing an organization's capabilities such as product innovation as an important strategic factor, this study will build upon the concept of dynamic capabilities and contribute towards this perspective through its findings and recommendations. This study was also designed to provide significant contribution to existing literature by investigating the relationship between product innovation and the dimensions or elements of brand equity; brand awareness, brand leadership, brand loyalty and brand image. By reviewing the literature on this topic, it was observed that most of the past researches paid limited attention to examining the link between product innovation and brand equity. Thus, the results of this study confirm the importance of product innovation as a key driver of brand equity.

\section{Limitations and Future Research Suggestions}

There are some limitations incurred in this study that can be considered in future researches. For example, the scope was only limited to passenger car users in northern region of Malaysia; particularly, at Penang, Perlis and Kedah. Therefore, it is suggest that future studies should test the variables by focusing on other areas and considering larger scope. Another limitation in this study refers to the difficulty of data collection, since many respondents were unwilling to answer the survey. Moreover, future researches can look into other antecedents of customer-based brand equity for the purpose of gaining better understandings about the relevant factors for building successful brand equity. Further research may also expand the findings of the present study by considering other product categories in different industry contexts. Last but not least, future researches may contemplate the applicability of the results in other countries and different cultural contexts.

\section{Conclusion}

Brand equity is regarded as an important criterion for determining brand success. For this reason, looking at the factors that can help firms to reinforce their brand 
equities is vital. The main objective of this study was to investigate the association between product innovation and brand equity in automotive industry. The findings showed that product innovation plays an important role in building brand equity and driving brand success. The study also confirmed that by focusing on product design with creative and differentiated features, firms can obtain favourable brand images as a result of positive consumers' perceptions. This study also proved that product innovation has significant positive relationship with all dimensions of brand equity; namely brand awareness, brand leadership, brand loyalty and brand image. By examining the relationships between the stated variables, it will reduce existing gaps in the literature and provide significant contribution to brand equity theory by confirming product innovation as key driver of brand success. It is believed that by focusing on product innovation, firms can gain competitive market power and minimize competitive threats.

A number of managerial implications can be revealed from the findings of this paper. For instance, product innovation is a key strategic factor that should be considered while designing branding strategies in order to enhance brand equity. Moreover, most of past studies on product innovation and brand equity were conducted in western cultures. This research provides evidence on its effect on brand equity from Southeast Asia; Malaysia. It is suggested that automotive brand managers should put sufficient investments in this strategic factor in an attempt to develop favourable brand image and positive consumers' evaluations. In this context, organizations should give greater attention to the importance of introducing new products with differentiated features such as quality and attractive product design. Moreover, business practitioners should be aware about the power of product innovation in influencing customers' word of mouth and future purchase behaviour.

In conclusion, this study reveal that product innovation plays an important role in driving brand success; because it reflects the characteristics and features of the designed product that influence consumer's demand and affect brand image. It is suggest that automotive manufacturers should ensure the innovation of their products consistently. For example, product design, intrinsic and extrinsic product attributes, appearance, performance and technological features are some of the important aspects that may affect consumers' purchase decisions and overall brand evaluation. Thus, automotive brand managers are advised to focus on product innovation activities such as creating new products with competitive features that are better or equivalent to those introduced by other competing brands. Such activities would enhance brand equity and improve brand performance in the long run.

\section{Acknowledgement}

I would like to thank the reviewers and editors of this journal for spending their valuable times to read my paper and provide me with useful suggestions to incorporate necessary amendments. I highly appreciate their support.

\section{Ethics}

This article is original and contains unpublished material. The corresponding author confirms that all of the other authors have read and approved the manuscript and no ethical issues involved.

\section{References}

Aaker, D.A., 1991. Managing Brand Equity. 1st Edn., Free Press, New York, ISBN-10: 0029001013, pp: 299.

Aaker, D.A., 1996. Building strong brands. Free Press, New York.

Bendixen, M., K.A. Bukasa and R. Abratt, 2004. Brand equity in the business-to-business market. Industrial Market. Manage., 33: 371-380. DOI: 10.1016/j.indmarman.2003.10.001

Beverland, M., J. Napoli and A. Lindgreen, 2007. Industrial global brand leadership: A capabilities view. Industrial Market. Manage., 36: 1082-1093. DOI: 10.1016/j.indmarman.2006.08.007

Boo, S., J. Busser and S. Baloglu, 2009. A model of customer-based brand equity and its application to multiple destinations. Tourism Manage., 30: 219-231. DOI: 10.1016/j.tourman.2008.06.003

Byrne, J.V., R. Beltechi, J.A. Yarnold, J. Birks and M. Kamran, 2010. Early experience in the treatment of intra-cranial aneurysms by endovascular flow diversion: A multicentre prospective study. PLoS One, 2: e12492-e12492. PMID: 20824070

Chimhundu, R., R.P. Hamlin and L. McNeill, 2010. Impact of manufacturer brand innovation on retailer brands. Int. J. Bus. Manage., 5: 10-18. DOI: $10.5539 /$ ijbm.v5n9p10

Chu, S. and H.T. Keh, 2006. Brand value creation: Analysis of the interbrand-business week brand value rankings. Market. Lett., 17: 323-31. DOI: $10.1007 / \mathrm{s} 11002-006-9407-6$

Curtis, T., R. Abratt and W. Minor, 2009. Corporate brand management in higher education: The case of ERAU. J. Product Brand Manage., 18: 404-413. DOI: $10.1108 / 10610420910989721$

Davcik, N.S. and N. Grigoriou, 2013. How brand oriented dynamic capabilities affect market share performance output: A resource-based theory approach. Social Science Electronic Publishing, Inc. 
Farquhar, P.H., 1989. Managing brand equity. Market. Res., 1: 24-33.

Hair, J.F., W.C. Black Jr., B.J. Babin, R.E. Anderson and R.L. Tatham, 2010. Multivariate Data Analyisis. 7th Edn., Upper Saddle River, Pearson Prentice Hall.

Hanaysha, J. and H. Hilman, 2015. Product innovation as a key success factor to build sustainable brand equity. Manage. Sci. Lett., 5: 567-576. DOI: $10.5267 /$ j.msl.2015.4.009

Henard, D.H. and P.A. Dacin, 2010. Reputation for product innovation: Its impact on consumers. J. Product Innovat. Manage., 27: 321-335. DOI: $10.1111 / \mathrm{j} .1540-5885.2010 .00719 . \mathrm{x}$

Hoeffler, S. and K.L. Keller, 2003. The marketing advantages of strong brands. J. Brand Manage., 10: 421-445. DOI: 10.1057/palgrave.bm.2540139

Holland, R., J. Schekleton and K.J. Na, 2011. The influence of product design of establishing brand equity. PhD Theses, Brunel University, UK.

Johne, A., 1999. Successful market innovation. Eur. J. Innovat. Manage., 2: 6-11. DOI: $10.1108 / 14601069910248838$

Kaplan, M.D., 2009. The relationship between perceived innovativeness and emotional product responses: A brand oriented approach. Innovative Market., 5: 39-47.

Karjalainen, T.M., 2006. Semantic Transformation in Design: Communicating Strategic Brand Identity Through Product Design References. 2nd Edn., University of Art and Design in Helsinki, Helsinki, ISBN-10: 9515581567, pp: 271.

Keller, K.L., 1993. Conceptualizing, measuring and managing customer-based brand equity. J. Market., 57: 1-22. DOI: 10.2307/1252054

Keller, K.L., 2001. Building customer-based brand equity. Market. Manage., 10: 14-19.

Keller, K.L., 2003. Strategic Brand Management: Building, Measuring and Managing Brand Equity. 2nd Edn., Prentice Hall, Upper Saddle River, ISBN-10: 0131006703, pp: 788.

Keller, K.L., 2008. Strategic Brand Management: Building, Measuring and Managing Brand Equity. 3rd Edn., Pearson/Prentice Hall, Harlow, ISBN-10: 0131888595, pp: 692.

Kingsland, B., 2007. Finding opportunities for innovation and growth. Spectrum Innovation Group.

Ko, E., K.H. Kim, S.H. Kim, G. Li and P. Zou et al., 2009. The relationship among country of origin, brand equity and brand loyalty: Comparison among USA, China and Korea. J. Global Acad. Market. Sci., 19: 47-58.

DOI: $10.1080 / 12297119.2009 .9707286$

Krejcie, R.V. and D.W. Morgan, 1970. Determining sample size for research activities. Educ. Psychol. Measure., 30: 607-610.
Kumar, V., T.R. Bohling and R.N. Ladda, 2003. Antecedents and consequences of relationship intention: Implications for transaction and relationship marketing. Industrial Market. Manage., 32: 667-676. DOI: 10.1016/j.indmarman.2003.06.007

Lassar, W., B. Mittal and A. Sharma, 1995. Measuring customer-based brand equity. J. Consumer Market., 12: 11-19. DOI: 10.1108/07363769510095270

Liaogang, H., G. Chongyan and L. Zi'an, 2007. Customerbased brand equity and improvement strategy for mobile phone brands: Foreign versus local in the Chinese market. Int. Manage. Rev., 3: 76-83.

Lieberman, M. and D. Montgomery, 1988. First-mover advantages. Strategic Manage. J., 9: 41-58. DOI: 10.1002/smj.4250090706

Malhotra, N.K., 1996. Marketing Research: An Applied Orientation. 2nd Edn., Prentice Hall, Upper Saddle River, N.J., ISBN-10: 0131257331, pp: 890.

Milenkov, M., 2012. Consumer's perception of product innovation and impact on the brand: How does the evaluation of product innovation impact brand equity?

Monö, R., 1997. Design for Product Understanding: The Aesthetics of Design from a Semiotic Approach. 1st Edn., Liber AB, Stockholm, ISBN-10: 914701105X, pp: 168.

Moradi, H. and A. Zarei, 2011. The impact of brand equity on purchase intention and brand preferencethe moderating effects of country of origin image. Aus. J. Basic Applied Sci., 5: 539-545.

Muller, W., 2001. Order and Meaning in Design. 1st Edn., Lemma Publishers, Utrecht, ISBN-10: 9051896298, pp: 354.

Myers, C., 2003. Managing brand equity: A look at the impact of attributes. J. Product Brand Manage., 12: 39-51. DOI: $10.1108 / 10610420310463126$

Nemati, A.R., K. Khan and M. Iftikhar, 2010. Impact of innovation on customer satisfaction and brand loyalty, a study of mobile phones users in Pakistan. Eur. J. Soc. Sci., 16: 299-306.

Nigam, A. and R. Kaushik, 2011. Impact of brand equity on customer purchase decisions: An empirical investigation with special reference to hatchback car owners in central Haryana. Int. J. Comput. Eng. Manage., 12: 121-128.

Otubanjo, O., 2013. A Discourse approach to brand leadership management. Int. J. Market. Stud., 5: 131-137. DOI: 10.5539/ijms.v5n2p131

Ross, S.D., 2006. A Conceptual framework for understanding spectator-based brand equity. J. Sport Manage., 20: 22-38.

Rubio, N. and M.J. Yague, 2009. Alternative panel models to evaluate the store brand market share: Evidence from the Spanish market. Eur. J. Market., 43: 110-138. DOI: 10.1108/03090560910923265 
Saridan, A.B., S. Mohamed and O. Intan, 2008. Enterprise strategies contributing to the success of Malaysian Biotechnology SMEs. Proceedings of the Oxford Business and Economics Conference Program, Jun. 22-24, Oxford, UK.

Schmitt, B.H. and A. Simonson, 1997. Marketing Aesthetics: The Strategic Management of Brands, Identity and Image. 1st Edn., The Free Press, New York, ISBN-10: 0684826550, pp: 345.

Sinapuelas, I.C. and S.R. Sisodiya, 2010. Do line extensions influence parent brand equity? An investigation of supermarket packaged goods. J. Product Brand Manage., 19: 18-26. DOI: $10.1108 / 10610421011018356$

Sriram, S., S. Balachander and M.U. Kalwani, 2007. Monitoring the dynamics of brand equity using Store-Level Data. J. Market., 71: 61-78. DOI: $10.1509 /$ jmkg.71.2.61

Stock, R.M., 2011. How does product program innovativeness affect customer satisfaction? A comparison of goods and services. J. Acad. Market. Sci., 39: 813-827. DOI: 10.1007/s11747-010-0215-4
Tabachnick, B.G. and L.S. Fidell, 2001. Using Multivariate Statistics. 4th Edn., Allyn and Bacon, Boston, ISBN-10: 0321189000, pp: 966.

Yang, C.H., 2008. Interrelationships between product innovation, country-of-origin effect, brand equity and purchase intention: An empirical study of notbook. MSc. Theses, China.

Yasin, N.M., M.N. Noor and O. Mohamad, 2007. Does image of country-of-origin matter to brand equity? J. Product Brand Manage., 16: 38-48. DOI: $10.1108 / 10610420710731142$

Yoo, B. and N. Donthu, 2001. Developing and validating a multidimensional consumer-based brand equity scale. J. Bus. Res., 52: 1-14.

DOI: 10.1016/S0148-2963(99)00098-3

Zhang, H., E. Ko, K.H. Kim, M. Hirose and B.J. Jeon, 2010. Roles of radical innovation on customer equity.

Appendix A: Confirmatory Factor Analysis

Product Innovation $(\mathrm{CR}=\mathbf{0 . 9 0 5}, \mathrm{AVE}=\mathbf{0 . 7 3 2})$

Fctor loadings

$\begin{array}{ll}\text { This car brand is highly innovative compared to other car brands in the market. } & 0.772\end{array}$

$\begin{array}{lr}\text { This car brand is frequently updated with new models. } & 0.686\end{array}$

This car brand is frequently supplemented with new features and specifications for the customers $\quad 0.833$

$\begin{array}{lr}\text { This car brand differs from competing models in the market. } & 0.807\end{array}$

This car brand frequently comprises new features which are meaningful to the customers. 0.899

$\begin{array}{lr}\text { This car is considered to be innovative in terms of product design. } & 0.768\end{array}$

Brand Equity Dimensions:

a. Brand awareness $(\mathrm{CR}=\mathbf{0 . 8 7 4}, \mathrm{AVE}=\mathbf{0 . 8 6 2})$

I know how the symbol of this car brand looks like.

I can recognize the brand of this car among other competing brands. $\quad 0.950$

$\begin{array}{lr}\text { I can quickly recall the symbol or logo of this car brand. } & 0.871\end{array}$

b. Brand loyalty $(\mathrm{CR}=\mathbf{0 . 8 6 0}, \mathrm{AVE}=\mathbf{0 . 6 4 7})$

I'm loyal to this car brand.

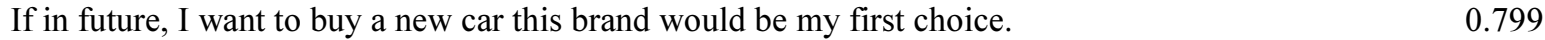

I will recommend this car brand to my friends.

c. Brand image $(\mathrm{CR}=\mathbf{0 . 8 4 5}, \mathrm{AVE}=\mathbf{0 . 5 8 7})$

This car brand has created a distinct image in my mind.

This car brand has given me whatever it promised to me.

0.713

This car brand provided me a better life style.

0.671

$\begin{array}{lr}\text { This car brand I'm using is associated with the manufacturer's image. } & 0.692\end{array}$

The staff of this car brand is able to build strong brand relationship with me 0.765

d. Brand leadership (CR $=0.862$, AVE $=0.753)$

$\begin{array}{lr}\text { This car brand is one of the leading brands in its category. } & 0.738\end{array}$

This car brand is growing in popularity.

0.716

$\begin{array}{lr}\text { This car brand is innovative, first with advances in products } & 0.666\end{array}$

$\begin{array}{lr}\text { This car brand is stylish when it comes to product design. } & 0.777\end{array}$ 